\title{
Identification of Quinones as Novel PIM1 Kinase Inhibitors
}

Richard L. Schroeder ${ }^{\mathrm{a}}$, Navneet Goyal ${ }^{\mathrm{a}}$, Melyssa Bratton ${ }^{\mathrm{b}}$, Ian Townley ${ }^{\mathrm{b}}$, Nancy A. Pham ${ }^{\mathrm{a}}$, Phan Tram $^{\mathrm{a}}$, Treasure Stone ${ }^{\mathrm{a}}$, Jasmine Geathers ${ }^{\mathrm{a}}$, Kathy Nguyen ${ }^{\mathrm{a}}$, and Jayalakshmi Sridhar ${ }^{\mathrm{a}, *}$

${ }^{a}$ Department of Chemistry, Xavier University of Louisiana, New Orleans, LA 70125, USA

${ }^{b}$ Cell and Molecular Biology Core Facility, Xavier University of Louisiana, New Orleans, LA 70125 USA

*Corresponding Author:

1, Drexel Dr., New Orleans, LA 70125

E-mail: jsridhar@xula.edu 


\begin{abstract}
PIM1 is a proto-oncogene encoding the serine/threonine PIM1 kinase. PIM1 kinase plays important roles in regulating aspects of cell cycle progression, apoptosis resistance, and has been implicated in the development of such malignancies as prostate cancer and acute myeloid leukemia among others. Knockout of PIM1 kinase in mice has been shown to be non-lethal without any obvious phenotypic changes, making it an attractive therapeutic target. Our investigation of anthraquinones as kinase inhibitors revealed a series of quinone analogs showing high selectivity for inhibition of the PIM kinases. Molecular modeling studies were used to identify key interactions and binding poses of these compounds within the PIM1 binding pocket. Compounds 1, 4, 7 and 9 inhibited the growth of DU-145 prostate cancer cell lines with a potency of $8.21 \mu \mathrm{M}, 4.06 \mu \mathrm{M}, 3.21 \mu \mathrm{M}$ and $2.02 \mu \mathrm{M}$.
\end{abstract}


Three isoforms (PIM-1, -2 and -3) of PIM kinases are encoded in the gene. The three members of the PIM family are serine/threonine kinases that exhibit very high homology and hence a certain amount of functional redundancy is found. These enzymes have little homology with the other members of protein kinase family. The PIM1 gene was initially identified as a proviral integration site in Moloney murine leukemia virus-induced mouse T-cell lymphomas ${ }^{1,2}$. PIM kinases are implicated in the development of solid tumors. DNA microarray analyses showed the overexpression of PIM1 in human prostate cancer in relation to the grade of the prostate cancer ${ }^{3}$. PIM kinases are critical mediators of hematopoeitic cell survival in both immunology and oncology 4 , 5 . PIM kinases potently cooperate with Myc, block apoptosis, and induce oncogenic transformation ${ }^{6-8}$. Sustained PIM1 expression is induced by many cytokines, mitogens and growth factors and PIM1 has been shown to be a major downstream target of the STATs (signal transducer and activator of transcription) ${ }^{9,10}$. PIM proteins role in human cancers such as prostate, pancreatic, colon, chronic lymphocytic leukemia, non-Hodgkin's lymphoma and multiple myeloma is well established ${ }^{10-15}$. It has been found that the knockout of PIM1 in mice is not lethal and its absence does not induce any immediately obvious phenotype ${ }^{16}$. This makes PIM1 an attractive target for chemotherapy.

Many classes of ATP competitive small molecule PIM1 inhibitors have been recently reported such as the pan-kinase inhibitor staurosporine and its related bisindolylmalemides ${ }^{17}$, imidazo[1,2-b]pyridazines ${ }^{18}$, pyridones ${ }^{19,20}$, flavonoids ${ }^{21,22}$, benzoisoxazoles ${ }^{23}$, cinnamic acids $^{24}$, thiazolidinones ${ }^{25}$, etc. Most of these molecules inhibit a variety of protein kinases, leading to questionable therapeutic value. Only SGI-1776 has been shown to fairly selective inhibitor of PIM kinases and demonstrated to effectively induce apoptosis in lymphocytic leukemia cells ${ }^{26,27}$. Given the prominent role of PIM kinases in numerous types of cancers, there is an urgent need to find more lead compounds to be developed as PIM kinase inhibitors that can exhibit good kinase selectivity profile.

Recently several reports have been published solving the crystal structure of PIM1 revealing several interesting features that is unique to PIM kinases ${ }^{24,28-32}$. The PIM1 protein has the typical secondary structural architecture with two domains connected by the hinge region apart from a distinctive $\mathrm{N}$-terminal peptide sequence. The PIM kinases contain the unique consensus sequence ERPXPX in the hinge region. The hinge region is atypical due to presence of a proline residue, Pro123, capable of making only a single hydrogen bond to the natural 
substrate ATP. Of the five kinases that share such a characteristic, three of them belong to the PIM kinase family. The P-loop of PIM1 is glycine rich containing residues GSGGFG. These aspects could play an important role in determining the potency and specificity of inhibitors. Our searches for lead molecules as kinase inhibitors lead us to quinolines and anthraquinones. Emodin a natural anthraquinone isolated from Rheum emodi, is a Traditional Chinese Medicine. Emodin is an established tyrosine kinase inhibitor ${ }^{33}$ and has been shown to inhibit several kinases such as HER2 ${ }^{33}$, Pim $1^{34}$, Casein Kinase $2^{35}$, DYRK1a ${ }^{36}, \mathrm{SGK}^{36}, \mathrm{JAK}^{37}$, etc.

Emodin was docked into the crystal structure of Pim1 kinase to understand the interactions and the features of emodin responsible for these interactions (Figure 1). The consensus docking postures revealed that the Emodin did not make any hydrogen bonds with the hinge region residues. Emodin made two hydrogen bonds with the residues Lys67 and Glu89. Additional $\pi$-alkyl interaction of the emodin aromatic rings with the residue Ile185 was also evidenced. Many groups have solved the crystal structure of Pim1 and a total of 53 crystal structures were found deposited on the RCSB PDB website (http://www.rcsb.org) ${ }^{38}$. All the ligands in the crystal structures were ATP-competitive or ATP-mimetic.A study of the interactions of the numerous ligands to the Pim1 protein revealed that only on hydrogen bond was made by the ligands with the hinge region to the residue Glu121. Other hydrogen bonds that were made by the ligands involved the residues Gly45, Asp128, Glu171, Asn172, Asp186. Additionally, hydrophobic interactions and $\pi$-methyl interactions were found for these ligands with the Pim1 residues Phe49, Ile185 and Leu174. These insights helped during the search for Emodin analogs that could act as potential inhibitors of Pim1 kinase.
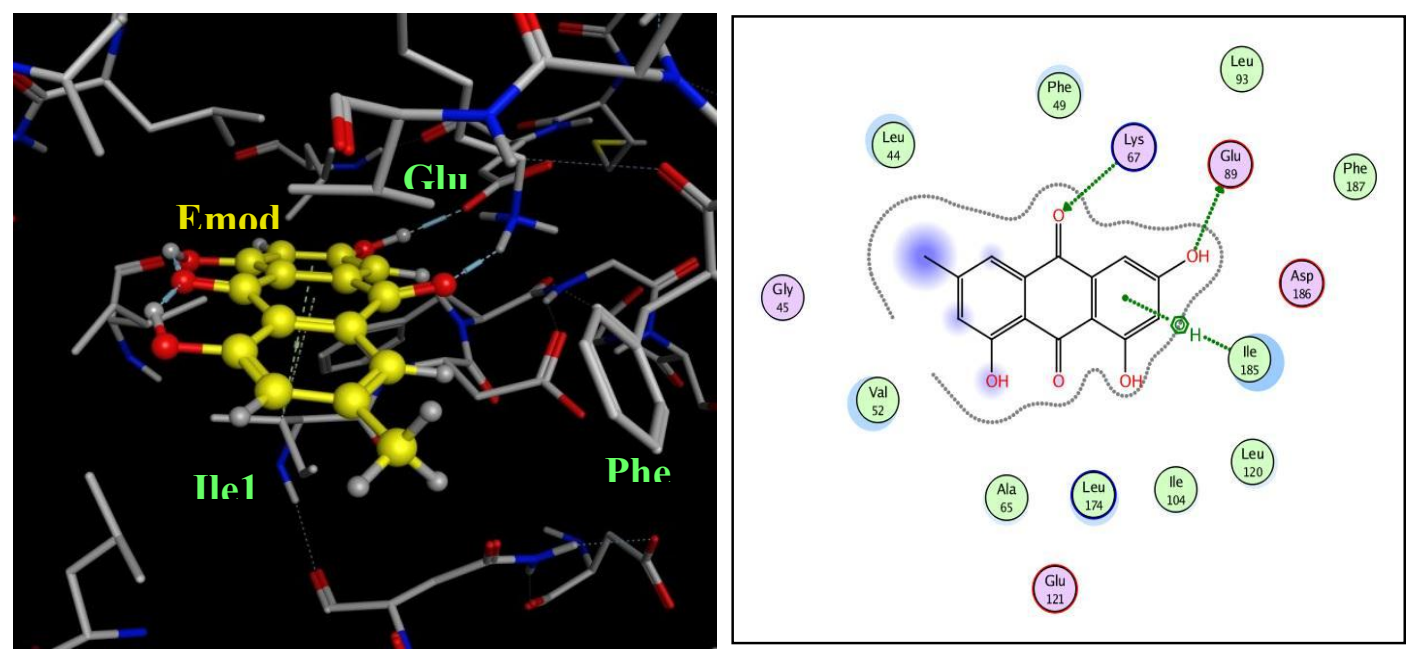

Figure 1: (A) Binding mode of emodin to the ATP binding site of Pim1 kinase (PDB ID: 2O64.pdb). The protein residues are shown as stick models and the emodin moecule is shown as yellow ball \& stick model. 
A 2D-pharmacophore involving the key functional groups of Emodin was designed and Sybyl-UNITY search was performed of the PUBCHEM and ZINC databases. The hitlist obtained was subjected to docking studies and based on the docking scores, a total of $\sim 40$ emodin analogues were chosen. The compounds 10, 12 and 14 were synthesized.

Scheme I

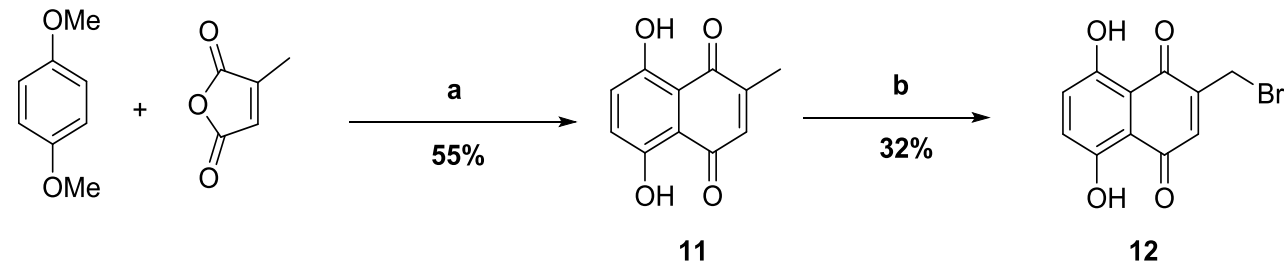

a) 1) $\left.\mathrm{AlCl}_{3}, \mathrm{NaCl}, 180^{\circ} \mathrm{C} 2\right) \mathrm{HCl}, 0^{\circ} \mathrm{C}$ b) NBS, $h v(240 \mathrm{~W}), \mathrm{CCl}_{4}$

Scheme II

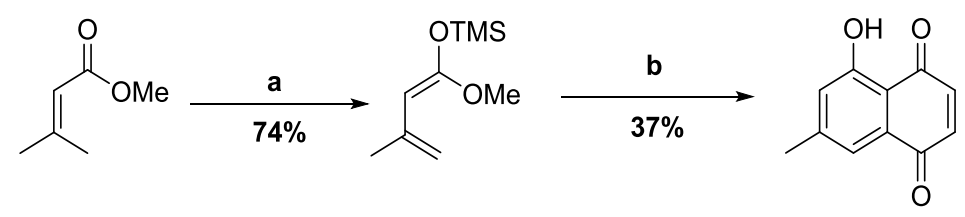

13

14

a) LDA, $\left(\mathrm{CH}_{3}\right)_{3} \mathrm{SiCl}, \mathrm{THF},-78^{\circ} \mathrm{C}$ b) 1) 1,4-benzoquinone, DCM, $0^{\circ} \mathrm{C}$ 2) $\mathrm{HCl}, \mathrm{MeOH}$

Figure 2: Schemes I and II outline the svnthesis of comnounds 12 and 14.

The precursor compound in the synthesis of compound 10, 2-formyl-1,4,5,8tetramethoxynaphthalene, was synthesized through known literature procedure ${ }^{39}$. Compound 11 was obtained through a double Friedel-Crafts acylation using 1,4-dimethoxybenzene and 2methylmaleic anhydride at high temperatures. Demethoxylation using $\mathrm{HCl}$ gave the desired product 11 (55\%). (Figure 2-Scheme I). Reported attempts using radical initiator catalysts in the bromination of compound i resulted in no desired product formation ${ }^{40}$. Two $120 \mathrm{~W}$ tungsten lamps were used to initiate hemolytic bond cleavage of NBS by placing the lamps close to the flask and allowing a vigorous reflux over $2 \mathrm{~h}$. Compound 12 was obtained after purification (32\%) (Figure 2-Scheme I). Formation of the trimethylsilyl diene 13 (74\%) in the synthesis of 14 proceeded through an LDA enolate reduction ${ }^{41}$. (Figure 2- Scheme II). The Diels-Alder cycloaddition between 13 and 1,4-quinone occurred slowly over $20 \mathrm{~h}$ at $0^{\circ} \mathrm{C}$. The corresponding 
hydroxynaphthoquinone 14 (37\%) was obtained through hydrolysis using $\mathrm{HCl}$ (Figure 2Scheme II). The synthesized compounds were characterized by ${ }^{1} \mathrm{H}-\mathrm{NMR},{ }^{13} \mathrm{C}-\mathrm{NMR}$ and Mass spectroscopies. All compounds had characteristic peaks with appropriate spectroscopic values (The experimental methods and spectroscopic charaterizations are detailed in Supporting information). An initial high-throughput in-vitro screen at $10 \mu \mathrm{M}$ concentration of all of the compounds and emodin showed that eight compounds exhibited perceptible inhibition of Pim1 kinase (Figure 3).<smiles>Cc1cc(O)c2c(c1)C(=O)c1cc(O)cc(O)c1C2=O</smiles>

Emodin<smiles>COc1c(O)c(O)c2c(c1O)C(=O)c1cc(C)cc(O)c1C2=O</smiles>

1<smiles>O=C1C2=C(C(=O)c3c(O)ccc(O)c31)[C@@H](O)[C@@H](O)[C@H](O)C2=O</smiles>

4<smiles>CC(C)C(C)OC1CC(=O)CC2C(=O)c3c(O)ccc(O)c3C(=O)C12</smiles><smiles>O=Cc1cc(O)c2c(c1O)C(=O)C=CC2=O</smiles>

10<smiles>COc1cccc2c1C(=O)c1c(O)ccc(O)c1C2=O</smiles>

2<smiles>Oc1ccc(O)c2c(O)c3c(O)ccc(O)c3c(O)c12</smiles>

5<smiles>CC(C)(C)OC1CC(=O)CC2C(=O)c3cccc(O)c3C(=O)C12</smiles><smiles>O=C1C=C(CBr)C(=O)c2c(O)ccc(O)c21</smiles>

12<smiles>O=C1C(CO)=C(CO)C(=O)c2c(O)ccc(O)c21</smiles><smiles>CC(=O)Oc1ccc(O)c2c1C(=O)C=CC2=O</smiles>

6<smiles>CC(C)(C)OC1CC(O)CC2C(=O)c3c(O)ccc(O)c3C(=O)C12</smiles><smiles>Cc1cc(O)c2c(c1)C(=O)C=CC2=O</smiles>

14

Figure 3. Structures of Emodin and compounds 1-10, 12 and 14 investigated for inhibition of Pim1 kinase. 
Since Emodin inhibited numerous kinases, the selectivity of the analogues chosen needed to be evaluated first. At this time Chemical Computing group (CCG) introduced a new module in
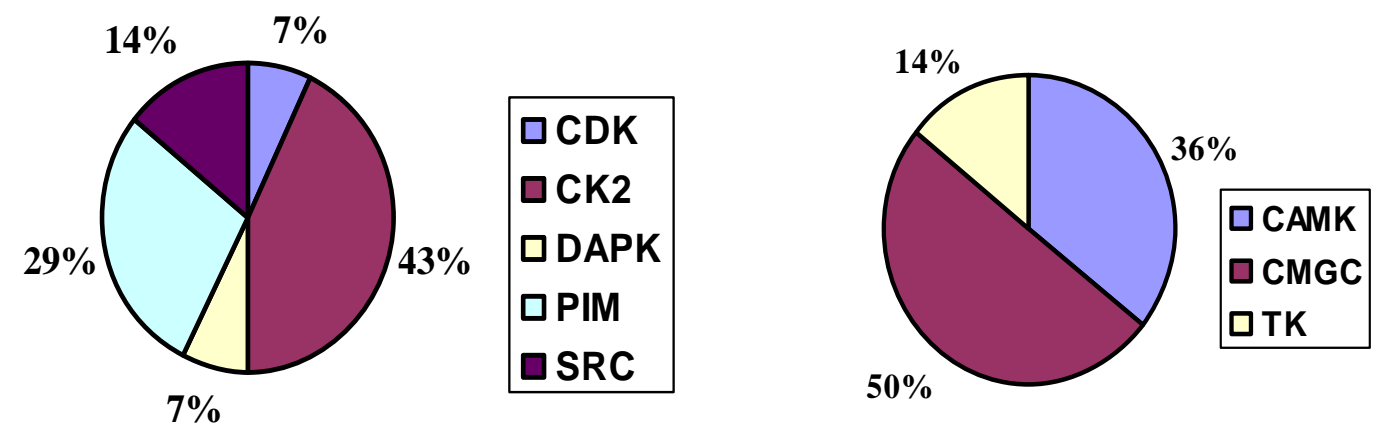

Figure 4. The results of kinase search in MOE using the 2D structure of compound 4 . The pie charts represent the identity of kinase structure hits for each family of kinases and the group for which these kinases belong.

MOE for kinase search. The kinase search module uses a database of kinases aligned globally. The kinase detection algorithm employed in MOE is based on the alignments with the kinase reference collections within the Hank's regions. Additionally a database containing a broad collection of chemical scaffolds or building blocks of available kinase inhibitors has been compiled in MOE. This database contains structures belonging to 10 classes of inhibitors (adenosines, staurosporines, oxoindoles, purines, isoquinolines, quinazlines, ureas, imidazoles, aminopyrimidines, and anthraquinones) along with the SMARTS strings that can be used for substructure search. The kinase search module had the option of ligand similarity search using tanimoto distance cutoff property to identify kinases that could be the potential target of the compound under study. Compound $\mathbf{4}$ was used as the study compound and an initial tanimoto cutoff value of 0.80 was specified. The results displayed only those structures that belonged to casein kinase II. This could have been the due of the presence of a crystal structure of casein kinase II with Emodin as the bound ligand. The stringent tanimoto distance cutoff value was relaxed to 0.60 for the next kinase search. The results (Figure 4) presented 5 protein kinases that could be the potential target for inhibition- CK2 (43\%), Pim kinases (29\%), SRC kinase (14\%), CDK (7\%) and DAPK (7\%). These five kinases belonged to the three families CMGC (50\%), CAMK $(36 \%)$ and TK $(14 \%)$. 
To understand the significance of the kinase selectivity search using MOE computing program, compound 4 was evaluated against a panel of 100 kinases at KINOMEscan (www.kinomescan.com). The compound(s) were screened at the $10 \mu \mathrm{M}$ concentration, and results for primary screen binding interactions are reported as '\% Ctrl', where lower numbers indicate stronger hits.

$\%$ Ctrl Calculation

$\left[\frac{\text { test compound signal - positive control signal }}{\text { negative control signal - positive control signal }}\right] \times 100$

The results presented in supporting information table 1 show that compound 4 that the only protein kinases strongly inhibited are CSNK1D (30\% control at 10 $\mu \mathrm{M})$, Pim1 (34\% control at $10 \mu \mathrm{M})$ and Pim3 $(36 \%$ control at $10 \mu \mathrm{M})$. The selectivity score $\mathrm{S}(35)$ was calculated as 0.022 . The KINOMEscan results were in excellent agreement with the kinase search performed in MOE with casein kinase and Pim kinases being the main protein kinases to be targeted by compound 4.

The dose response curves were performed for the inhibition of Pim1 kinase by Emodin, the eight compounds identified in the initial high-throughput screening (compounds 1-9) and three synthesized compounds (compounds 10, 12 and 14) (Table 1). Emodin exhibited an $\mathrm{IC}_{50}$ value of $2.5 \mu \mathrm{M}$ in the in-vitro assay. Compounds 3, 6, 7 and 9 showed IC50 values of $7.4 \mu \mathrm{M}$, $3.0 \mu \mathrm{M}, 3.6 \mu \mathrm{M}$ and $3.5 \mu \mathrm{M}$ which were equivalent to that of Emodin. Compound 2 and 4 presented $\mathrm{IC}_{50}$ values of $11.6 \mu \mathrm{M}$ and $19.2 \mu \mathrm{M}$ which were in the low micro molar range and close to that of Emodin. Only compound 5 showed poor inhibition potency for Pim1 kinase with an $\mathrm{IC}_{50}$ value of $57.1 \mu \mathrm{M}$. Compounds $\mathbf{1 0}, \mathbf{1 2}$, and 14 were found to have $\mathrm{IC}_{50}$ values of $28 \mu \mathrm{M}$, $27 \mu \mathrm{M}$, and $28 \mu \mathrm{M}$, respectively. 
Table 1. Inhibition of

Pim1 kinase by emodin and compounds 1 to $\mathbf{1 0}$, 12 and 14.

\begin{tabular}{|c|c|}
\hline Compound & $\mathbf{I C}_{\mathbf{5 0}}(\boldsymbol{\mu} \mathbf{M})$ \\
\hline Emodin & 2.5 \\
\hline 1 & 21.4 \\
\hline 2 & 11.6 \\
\hline 3 & 7.4 \\
\hline 4 & 19.2 \\
\hline 5 & 57.1 \\
\hline 6 & 3.0 \\
\hline 7 & 3.6 \\
\hline 8 & 23.8 \\
\hline 9 & 3.5 \\
\hline 10 & 28.0 \\
\hline 11 & 27.0 \\
\hline 12 & 28.0 \\
\hline
\end{tabular}

Pim1 is highly expressed in a significant fraction of human prostate cancer in which cMYC was also overexpressed. It was determined that synergistic interaction of Pim1 and c-MYC was critically dependent on Pim1 kinase activity implying that inhibition of Pim1 kinase activity should be effective in cancer treatment. To determine whether these compounds were effective in-vivo, we tested the growth inhibitory properties of Emodin and compounds 1, 4, 7 and 8 on the human prostate cancer cell line DU-145 that is known to express PIM- ${ }^{42}$. Figure 5 shows

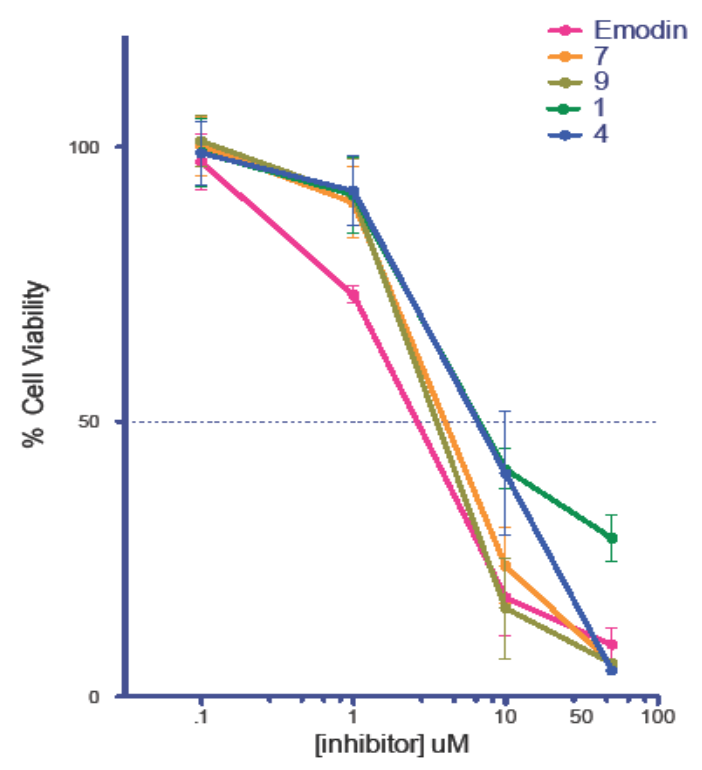

Figure 5: Growth inhibition curve for DU-145 cells treated with compounds $1,4,7,9$ and Emodin. 
that compounds 1, 4, 7,9 and Emodin inhibit the growth of DU-145 cells with an $\mathrm{IC}_{50}$ of 3.93 $\mu \mathrm{M}, 8.21 \mu \mathrm{M}, 4.06 \mu \mathrm{M}, 3.21 \mu \mathrm{M}$ and $2.02 \mu \mathrm{M}$. These data show that the Emodin and its analogs show good promise in anticancer activities on prostate cancer cell lines.

Docking studies of Emodin and compounds 1-6 were performed on the known crystal structure of Pim1 kinase protein (PDB ID: 2O64.pdb). The binding modes of compounds 1-6 to Pim1 protein were similar to that of Emodin in that they occupied the ATP-binding pocket, but did not show any hydrogen bonding interaction with the hinge region residues (Figure 5). One of the carbonyl groups and its adjacent hydroxyl group of the compounds makes hydrogen bonds to the side chains of two highly conserved residues, Lys67 and/or Glu89. The binding interactions of the compounds with the best inhibition potency are shown in figure 5A for compound $\mathbf{3}$ and figure $5 \mathrm{~B}$ for compound $\mathbf{6}$. The binding postures show the planar portion of the molecules aligned in the cavity in such a way that $\pi$-alkyl group interactions could be maximized with the numerous hydrophobic residues lining the top and bottom regions of the binding site. From a study of all the available crystal structures and the co-crystallography study by the Bremer group $^{29}$, it is evident that all of the small molecule inhibitors bind in the ATP binding site of Pim1, and most of them are localized near the hinge and the conserved Lys67/Glu89/Phe187 region. The fact that our compounds bind to Lys67 and/or Glu89, demonstrates that they satisfy the requirements of hydrogen bonding to Lys67/Glu89 region as exemplified by the previous studies Pim1. The docking scores of the compounds had a trend similar to that of their inhibition potency with the more potent compounds having lower scores indicating more favorable poses (supporting document, table 2). 

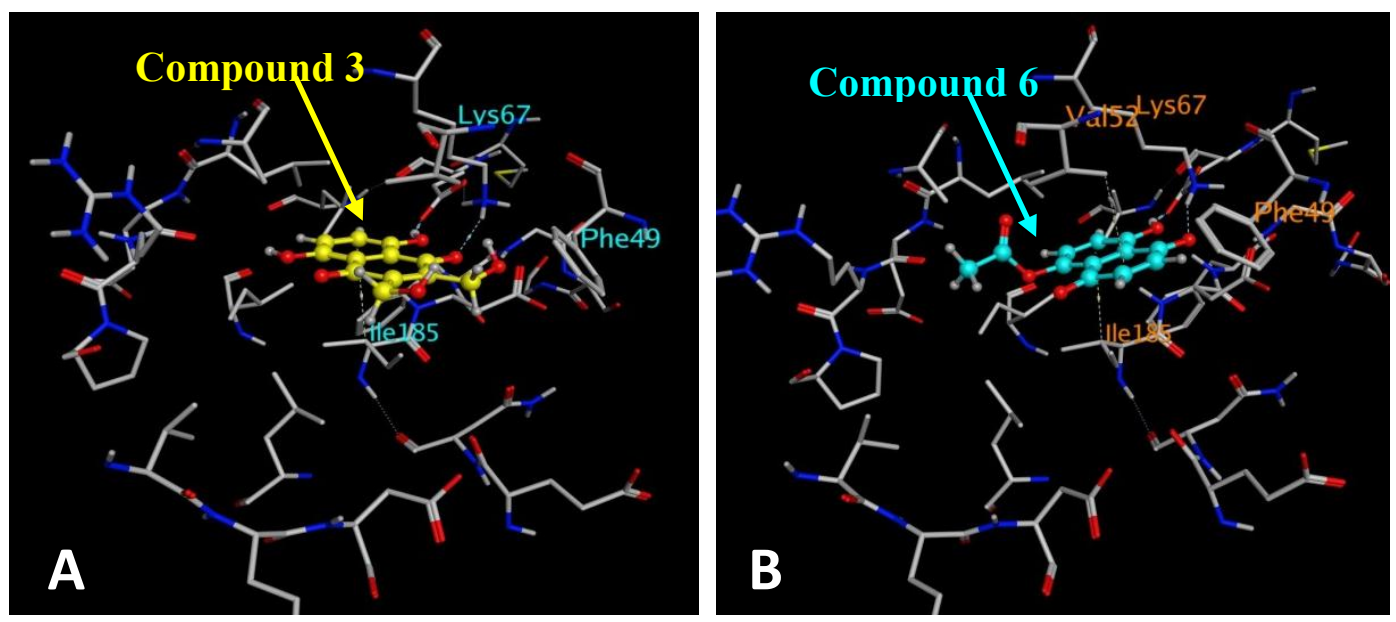

Figure 6: Binding mode of compounds $3(\mathrm{~A})$ and $6(\mathrm{~B})$ to the ATP-binding pocket of Pim1 kinase (PDB ID: 2O64.pdb). The

In conclusion, a new series of compounds have been identified as inhibitors of Pim1 kinase. They have excellent effect on the arrest of growth in the prostate cancer cells DU145. The selectivity of the representative compound 4 for the Pim1, Pim2 and CSNK1D was discovered by the KINOMEscan assay against a panel of 100 kinases. Docking studies have revealed the binding orientations of these molecules in the ATP-binding cavity of the Pim1 protein. The insights obtained from the docking studies will help us to design and develop new Pim1 inhibitors with improved potency while maintaining the selectivity for Pim kinases.

\section{Acknowledgement}

This research work was funded by the NIH-RCMI (2G12MD007595-06) from the National Institute on Minority Health and Health Disparities and the startup grant by the Louisiana Cancer Research Consortium. Additional support from the Department of Defense Award (W81XWH11-1-0105), the Louisiana Biomedical Research Network (LBRN- P20GM103424) is greatfully acknowledged. We thank the NIH-BUILD Grant-TL4MD009607 and the Center for Undergraduate Research at Xavier University of Louisiana for supporting the students who worked on this project. The contents are solely the responsibility of the authors and do not represent the official views of NIH.

\section{Supplementary data}

Supplementary data (synthetic protocols, compound characterization data, assay details, and supplementary figures) associated with this article can be found in the online version. 


\section{Reference}

1. H. T. Cuypers; G. Selten; W. Quint; M. Zijlstra; E. R. Maandag; W. Boelens; P. van Wezenbeek; C. Melief; A. Berns Cell. 1984, 37, 141.

2. $\quad$ G. Selten; H. T. Cuypers; A. Berns EMBO J. 1985, 4, 1793.

3. $\quad$ S. M. Dhanasekaran; T. R. Barrette; D. Ghosh; R. Shah; S. Varambally; K. Kurachi; K. J. Pienta; M. A. Rubin; A. M. Chinnaiyan Nature. 2001, 412, 822.

4. J. Domen; N. M. van der Lugt; P. W. Laird; C. J. Saris; A. Berns Leukemia. 1993, 7 Suppl 2, S108.

5. $\quad$ N. M. van der Lugt; J. Domen; E. Verhoeven; K. Linders; H. van der Gulden; J. Allen; A. Berns EMBO J. 1995, 14, 2536.

6. J. D. Allen; E. Verhoeven; J. Domen; M. van der Valk; A. Berns Oncogene. 1997, 15, 1133.

7. M. van Lohuizen; S. Verbeek; P. Krimpenfort; J. Domen; C. Saris; T. Radaszkiewicz; A. Berns Cell. 1989, 56, 673.

8. S. Verbeek; M. van Lohuizen; M. van der Valk; J. Domen; G. Kraal; A. Berns Mol Cell Biol. 1991, 11, 1176.

9. S. Matikainen; T. Sareneva; T. Ronni; A. Lehtonen; P. J. Koskinen; I. Julkunen Blood. 1999, 93, 1980.

10. Z. Wang; N. Bhattacharya; M. Weaver; K. Petersen; M. Meyer; L. Gapter; N. S. Magnuson J Vet Sci. 2001, 2, 167.

11. R. Grundler; L. Brault; C. Gasser; A. N. Bullock; T. Dechow; S. Woetzel; V. Pogacic; A. Villa; S. Ehret; G. Berridge; A. Spoo; C. Dierks; A. Biondi; S. Knapp; J. Duyster; J. Schwaller J Exp Med. 2009, 206, 1957.

12. Y. Y. Li; B. K. Popivanova; Y. Nagai; H. Ishikura; C. Fujii; N. Mukaida Cancer Res. 2006, 66, 6741 .

13. L. Pasqualucci; P. Neumeister; T. Goossens; G. Nanjangud; R. S. Chaganti; R. Kuppers; R. Dalla-Favera Nature. 2001, 412, 341.

14. B. K. Popivanova; Y. Y. Li; H. Zheng; K. Omura; C. Fujii; K. Tsuneyama; N. Mukaida Cancer Sci. 2007, 98, 321.

15. A. Valdman; X. Fang; S. T. Pang; P. Ekman; L. Egevad Prostate. 2004, 60, 367.

16. P. W. Laird; N. M. van der Lugt; A. Clarke; J. Domen; K. Linders; J. McWhir; A. Berns; M. Hooper Nucleic Acids Res. 1993, 21, 4750.

17. A. N. Bullock; J. E. Debreczeni; O. Y. Fedorov; A. Nelson; B. D. Marsden; S. Knapp J Med Chem. 2005, 48, 7604.

18. V. Pogacic; A. N. Bullock; O. Fedorov; P. Filippakopoulos; C. Gasser; A. Biondi; S. Meyer-Monard; S. Knapp; J. Schwaller Cancer Res. 2007, 67, 6916.

19. I. W. Cheney; S. Yan; T. Appleby; H. Walker; T. Vo; N. Yao; R. Hamatake; Z. Hong; J. Z. Wu Bioorg Med Chem Lett. 2007, 17, 1679.

20. Z. A. Knight; K. M. Shokat Chem Biol. 2005, 12, 621.

21. S. Holder; M. Lilly; M. L. Brown Bioorg Med Chem. 2007, 15, 6463.

22. S. Holder; M. Zemskova; C. Zhang; M. Tabrizizad; R. Bremer; J. W. Neidigh; M. B. Lilly Mol Cancer Ther. 2007, 6, 163.

23. A. C. Pierce; M. Jacobs; C. Stuver-Moody J Med Chem. 2008, 51, 1972. 
24. K. Qian; L. Wang; C. L. Cywin; B. T. Farmer, 2nd; E. Hickey; C. Homon; S. Jakes; M. A. Kashem; G. Lee; S. Leonard; J. Li; R. Magboo; W. Mao; E. Pack; C. Peng; A. Prokopowicz, 3rd; M. Welzel; J. Wolak; T. Morwick J Med Chem. 2009, 52, 1814.

25. Z. Xia; C. Knaak; J. Ma; Z. M. Beharry; C. McInnes; W. Wang; A. S. Kraft; C. D. Smith J Med Chem. 2009, 52, 74.

26. $\quad$ N. S. Magnuson; Z. Wang; G. Ding; R. Reeves Future Oncol. 2010, 6, 1461.

27. S. M. Mumenthaler; P. Y. Ng; A. Hodge; D. Bearss; G. Berk; S. Kanekal; S. Redkar; P. Taverna; D. B. Agus; A. Jain Mol Cancer Ther. 2009, 8, 2882.

28. M. D. Jacobs; J. Black; O. Futer; L. Swenson; B. Hare; M. Fleming; K. Saxena J Biol Chem. 2005, 280, 13728.

29. A. Kumar; V. Mandiyan; Y. Suzuki; C. Zhang; J. Rice; J. Tsai; D. R. Artis; P. Ibrahim; R. Bremer J Mol Biol. 2005, 348, 183.

30. K. C. Qian; L. Wang; E. R. Hickey; J. Studts; K. Barringer; C. Peng; A. Kronkaitis; J. Li; A. White; S. Mische; B. Farmer J Biol Chem. 2005, 280, 6130.

31. M. N. Schulz; J. Fanghanel; M. Schafer; V. Badock; H. Briem; U. Boemer; D. Nguyen; M. Husemann; R. C. Hillig Acta Crystallogr.,Sect.D. 2011, 67, 156.

32. Y. Xiang; B. Hirth; G. Asmussen; H. P. Biemann; K. A. Bishop; A. Good; M. Fitzgerald; T. Gladysheva; A. Jain; K. Jancsics; J. Liu; M. Metz; A. Papoulis; R. Skerlj; J. D. Stepp; R. R. Wei Bioorg Med Chem Lett. 2011, 21, 3050.

33. L. Zhang; Y. K. Lau; L. Xi; R. L. Hong; D. S. Kim; C. F. Chen; G. N. Hortobagyi; C. Chang; M. C. Hung Oncogene. 1998, 16, 2855.

34. G. Cozza; M. Mazzorana; E. Papinutto; J. Bain; M. Elliott; G. di Maira; A. Gianoncelli; M. A. Pagano; S. Sarno; M. Ruzzene; R. Battistutta; F. Meggio; S. Moro; G. Zagotto; L. A. Pinna Biochem J. 2009, 421, 387.

35. H. Yim; Y. H. Lee; C. H. Lee; S. K. Lee Planta Med. 1999, 65, 9.

36. S. Sarno; E. de Moliner; M. Ruzzene; M. A. Pagano; R. Battistutta; J. Bain; D. Fabbro; J. Schoepfer; M. Elliott; P. Furet; F. Meggio; G. Zanotti; L. A. Pinna Biochem J. 2003, 374, 639.

37. A. Muto; M. Hori; Y. Sasaki; A. Saitoh; I. Yasuda; T. Maekawa; T. Uchida; K. Asakura;

T. Nakazato; T. Kaneda; M. Kizaki; Y. Ikeda; T. Yoshida Mol Cancer Ther. 2007, 6, 987.

38. H. M. Berman; J. Westbrook; Z. Feng; G. Gilliland; T. N. Bhat; H. Weissig; I. N.

Shindyalov; P. E. Bourne Nucleic Acids Res. 2000, 28, 235.

39. Y. T. Tanoue, A Bull. Chem. Soc. Jpn. 1988, 61, 2039.

40. J. Dessolin; C. Biot; E. Davioud-Charvet J Org Chem. 2001, 66, 5616.

41. L. F. Tietze; K. M. Gericke; R. R. Singidi; I. Schuberth Org Biomol Chem. 2007, 5, 1191.

42. X. F. Hu; J. Li; S. Vandervalk; Z. Wang; N. S. Magnuson; P. X. Xing J Clin Invest. 2009, $119,362$. 
Graphical Abstract

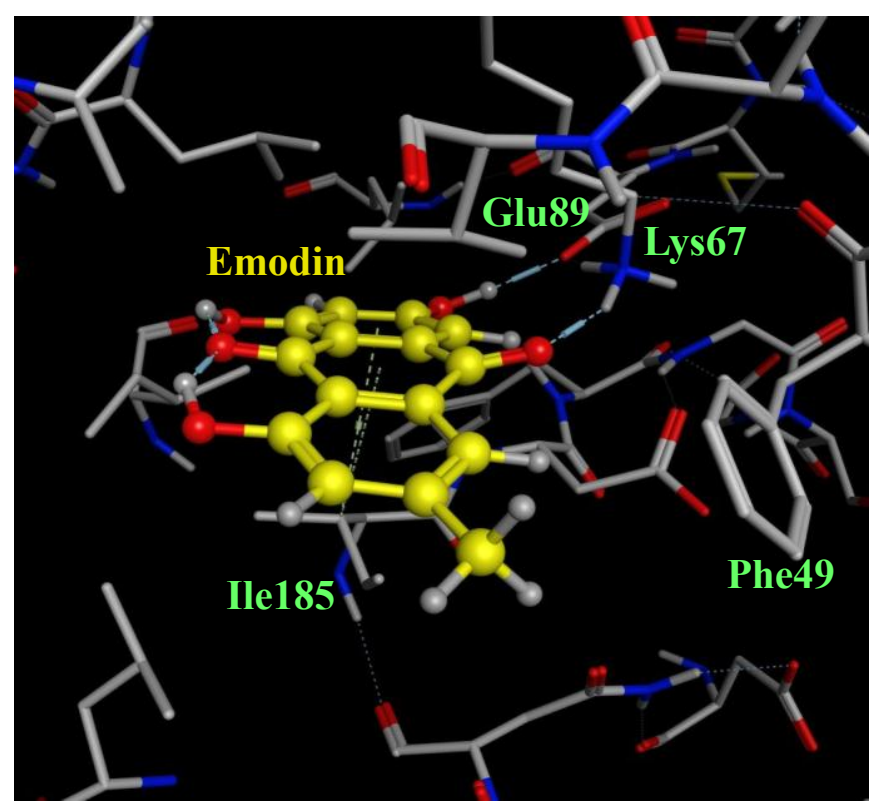

